\title{
Application of quantitative Termography for detecting contact fatigue anomalies in spur cylindrical gears
}

by J. M. Oliveira Neto*, J. F. Maribondo** and W. F. Amorin Júnior**

*Federal University of Paraíba, Campus-I - Cidade universitária Lot, João Pessoa, Paraíba, Brasil, joao engmec@outlook.com

${ }^{* *}$ Federal University of Campina Grande, Aprígio Veloso Str., no 882, Campina Grande, Paraíba, Brasil, juscelinodefarias@oi.com.br

${ }^{* *}$ Federal University of Campina Grande, Aprígio Veloso Str., no 882, Campina Grande, Paraíba, Brasil, engenhariabrasileira1@gmail.com

\section{Abstract}

Gear failures arise in most cases due to contact fatigue through cyclic stresses from the tooth contact, setting the temperature rise. The present work aims to verify the feasibility of applying quantitative Thermography in its active and passive modes and in controlled environment to detect the conditions of lack of lubrication and flaws on the surfaces of the teeth of a cylindrical spur gear. The technique was able to detect the absence of lubrication, contrary to what was found for flaws in tooth surfaces. 